Bot. Helv. 118 (2008): $1-12$

0253-1453/08/010001-12

DOI 10.1007/s00035-008-0825-3

(C) Birkhäuser Verlag, Basel, 2008

Botanica Helvetica

\title{
Postglacial recolonisation of plants in the western Alps of Switzerland
}

\section{Christian Parisod}

Department of Ecology and Evolution, University of Lausanne, CH-1015 Lausanne Current address: Laboratoire de Biologie Cellulaire, INRA, Centre de Versailles, F-78026

Versailles; e-mail: cparisod@versailles.inra.fr

Manuscript accepted 12 December 2007

\begin{abstract}
Parisod C. 2008. Postglacial recolonisation of plants in the western Alps of Switzerland. Bot. Helv. 118: 1-12.

During the Quaternary glaciations, alpine plants could only persist in scattered icefree areas located either within the Alps or at their periphery. From there, species recolonised the Alps after the retreat of glaciers, and efforts have been made to reconstruct the main migration pathways using either floristic information (i.e. patterns of species distribution) or studies of infraspecific genetic variation (i.e. distribution patterns of genotypes or lineages). This review article compiles floristic and molecular information about the recolonisation of the western Swiss Alps. Three main pathways of recolonisation have been suggested in the literature: the Rhodanian pathway (from south-western refugia, along the Rhone valley), the transalpine southern pathway (from southern refugia, crossing the line of main summits through high-altitude passes), and the transalpine eastern pathway (from eastern refugia, along the Rhine valley and across the northern Alps). Floristic data mainly support the Rhodanian pathway, as many western Alpine species occur along this route, as well as the transalpine southern pathway, as some southern species occur in the vicinity of the relevant passes. In contrast, few species show distribution patterns consistent with the transalpine eastern pathway. Recent molecular studies have supported the floristic patterns. In particular, distinct genetic lineages of the widespread alpine species Biscutella laevigata were distributed along the Rhodanian pathway and transalpine southern pathway, and genetic diversity was especially high in the central area, where these recolonisation pathways met. Knowledge about past migration routes of plants is essential to understand the response of species to climate change and the present patterns of biodiversity within the Alps.
\end{abstract}


Key words: Biscutella laevigata, historical biogeography, molecular phylogeography, plant migration, transalpine migration.

\section{Introduction}

On every continent, mountainous regions represent areas of high biodiversity (Körner 1999; Ozenda 2002) and the European Alps, which are the habitat of 4500 plant species, are no exception (Aeschimann et al. 2004). The distribution of plant species within the Alps is partly determined by ecological factors, such as climate or bedrock type (Wohlgemuth 2002), but also by historical factors, such as the recent Quaternary glaciations (Comes and Kadereit 1998). During these glaciations, most of the Alps were covered by ice (Kelly et al. 2004), and plants could only persist in scattered ice-free refugia, from where plants must have recolonised the Alps after the retreat of the glaciers. Present patterns of biodiversity within the Alps probably reflect to a large extent opportunities for species to either survive locally or re-immigrate after the glaciations. Investigating the glacial history of species in alpine landscapes is therefore of vital importance to understand not only the origin of their biodiversity (Gugerli and Holderegger 2001), but also conditions for the persistence of this biodiversity. For example, endemic alpine species are presently mainly found in areas that probably served as glacial refugia (Pawlowski 1970; Ozenda 1995), suggesting that these areas allowed the long-term persistence of species during periods of climate change, and that their isolation during these periods promoted speciation (Tribsch and Schönswetter 2003).

The location of glacial refugia for plant species within the Alps has been the focus of many studies (Brockmann-Jerosch and Brockmann-Jerosch 1926; Merxmüller 1952). Floristic data have suggested the existence of large peripheral refugia in the external Alps as well as small ice-free areas (nunataks) in the central Alps (Stehlik 2000). Such evidence has recently been confirmed by studies reconstructing the history of various alpine species using molecular phylogeography, i.e. geographic patterns of genetic variation (reviewed in Schönswetter et al. 2005). For example, for the western Alps of Switzerland, both types of studies consistently indicated that the southern peripheral Alps and the central area of Zermatt served as refugia for plant species during the last glacial maximum. Further molecular studies have confirmed additional glacial refugia, such as the Simplon area (Bettin et al. 2007) and several limestone areas of the northern peripheral Alps (Parisod and Besnard 2007). Interestingly, these areas are characterised by high species diversity as well as high genetic diversity within species. It therefore seems that biogeographic processes have influenced patterns of biodiversity within the Alps similarly across taxonomic levels (Schönswetter et al. 2005; Tribsch and Schönswetter 2003; Vellend and Geber 2005), so that information from molecular and floristic studies can be tentatively combined to reconstruct biogeographic processes.

While the locations of glacial refugia are meanwhile well established, it still remains uncertain how species have recolonised the Alps after the last glacial maximum. Attempts to reconstruct the postglacial migration of species from their refugia into other parts of the Alps have been based on the assumption that such range expansions have had an important impact on the distribution of species as well as on patterns of infraspecific genetic variation. The two main expectations are that (a) species diversity as well as infraspecific genetic diversity should decrease with increasing distance from the refugia along the main migration routes, and (b) sites located close to each other 
along the same migration route should have a great floristic similarity and a great genetic similarity within species.

For the western Alps of Switzerland (Vaud, Valais, Berner Oberland), floristic information has suggested a few main recolonisation pathways. These will be reviewed in the present article. It is then examined to what extent these recolonisation pathways are supported by recent studies of molecular phylogeography.

\section{Results of floristic studies}

The postglacial expansion of species in the western Swiss Alps took place in two successive waves: during the tardiglacial period (17'000-10'200 years before present) and then during the postglacial period (the last 10'200 years). The climate of the tardiglacial was still rather cold and dry, and several heliophilous species underwent a rapid expansion, advantaged by the low-competition habitats provided by the retreat of glaciers (Burga and Perret 1998). Most xerophilous species and several oromediterranean species presently found in the western Swiss Alps (e.g. Coronilla minima, Koeleria vallesiana) probably immigrated at this time, before the arrival of trees (Delarze 1987; Laydu-Mange 1999). In contrast, the climate of the postglacial period was characterised by increased precipitation, and woodland began to cover the Alps at low elevations, restricting the migration of heliophilous species (Burga and Perret 1998). Some xerophilous species with ruderal life history possibly still colonised the Western Alps during this period through open Pinus woodlands or river shorelines.

Recolonisation pathways used by plant species after the last glacial maximum have traditionally been deduced from the distribution of particular species (Briquet 1906; Brockmann-Jerosch and Brockmann-Jerosch 1926; Merxmüller 1952). Based on such floristic evidence, three main recolonisation pathways inside the western Alps have been postulated (Fig. 1): the Rhodanian pathway, from the western refugia to the east following the Rhone valley; the transalpine eastern pathway, from eastern refugia through the Rhine and Danube valleys to the west across the northern or central Alps; and the transalpine southern pathway, from southern refugia to the north across the Pennine Alps.

\section{The Rhodanian pathway}

The Rhodanian pathway is well established and has probably been the main recolonisation route for thermophilous species that took refuge in south-western Europe, at the front of the Rhone glacier, during the last glacial maximum (Christ 1920). When the Rhone glacier retreated, species could first recolonise the French Alps (Haute Savoie) and the Jura mountains (Briquet 1906), which may explain the floristic similarities between the Savoyan flora and the flora of the Jura mountains (Briquet 1890). The Rhone valley and the Chablais region (relatively low alpine ranges between the Haute Savoie and the Rhone valley) then offered a natural pathway for the recolonisation of the western Swiss Alps because of their numerous xerothermophilous meadows (Briquet 1900). This immigration route is indicated by the fact that several xerophilous species found in the Valais also occur in dry habitats of the Chablais region, while they are absent from the adjacent Piemont region in the Italian Alps (Delarze 1987). These species (e.g. Adonis vernalis, Arabis collina, Gagea saxatilis) must therefore have colonised the Valais from the west, and not from the south. 

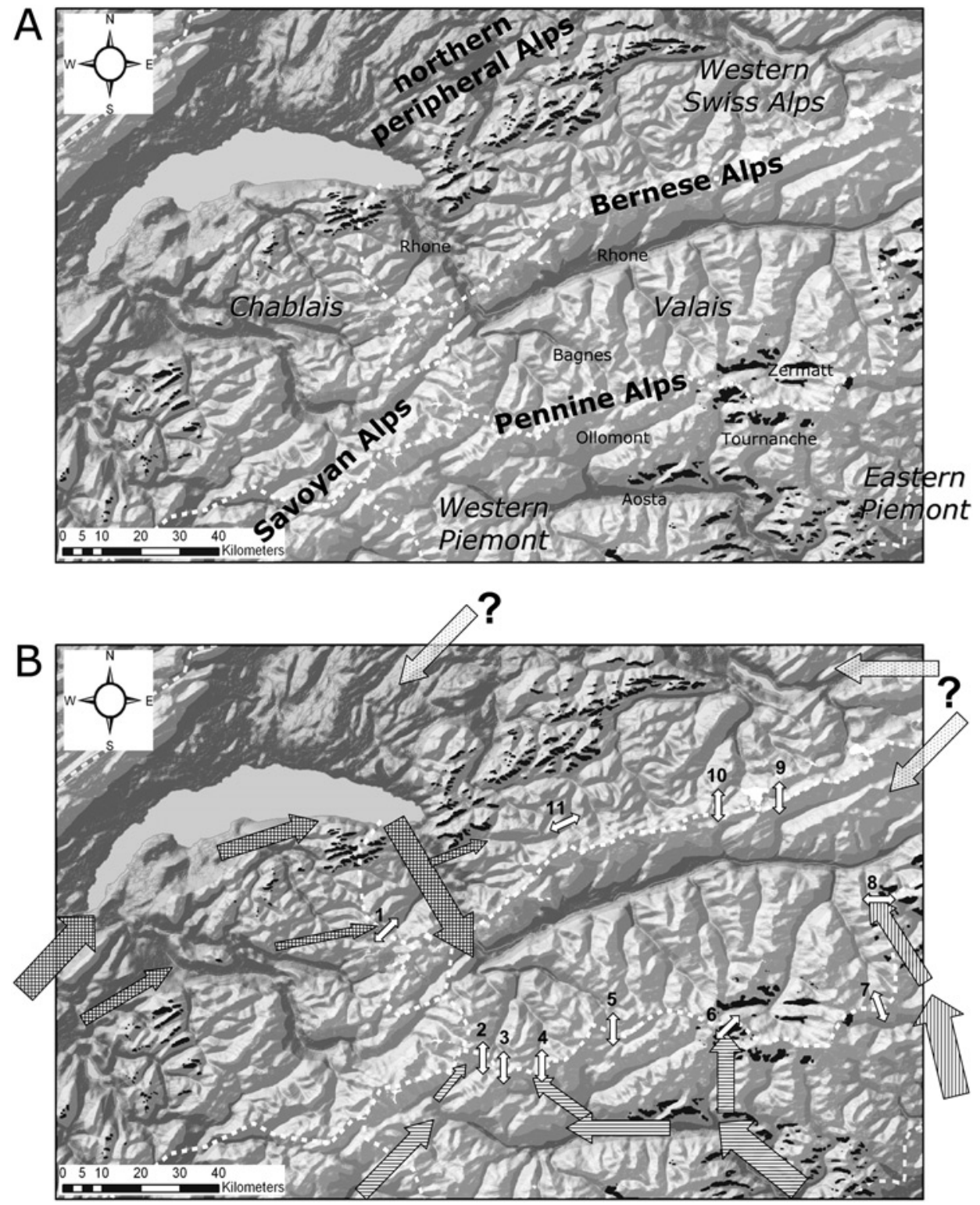

Fig. 1. A: The western Alps of Switzerland. The areas shaded in black show the putative peripheral refugia and the central nunataks (Stehlik 2000). The natural districts are delimited with white lines following Theurillat et al. (1993). The names of the main mountain ranges are in bold and those of cited locations are smaller. B: Putative recolonisation pathways in the western Alps of Switzerland based on floristic evidence. Crosshatched arrows represent the "Rhodanian pathway". Dotted arrows present the putative "transalpine eastern pathway". The "transalpine southern pathway" is indicated by hatched arrows (horizontal in the "Western Piemont" and vertical in the "Eastern Piemont"). Double arrows represent the major passes through which species putatively crossed the line of main summits: 1 - Pas-de-Morgin (1370 m) / Col de la Forclaz (1526 m); 2 - Fenêtre Ferret (2490 m); 3 - Col du Grand St. Bernard (2475 m); 4-Fenêtre Durand (2812 m);5 - Col du Collon (3130 m); 6 - Theodulpass (3333 m); 7 - Antronapass (2844 m) / Zwischenbergenpass (3248 m); 8 - Simplonpass (2005 m); 9 Lötschenpass (2690 m); 10 - Gemmipass (2314 m); 11 - Col du Pillon (1546 m). 
Several Mediterranean species (e.g. Anacamptis pyramidalis, Astragalus monspessulanus, Asplenium ceterach, Genista tinctoria, Hieracium tomentosum, Ononis natrix, O. pusilla, Orlaya grandiflora, Trinia glauca) show a distribution pattern that is thinning out from the south-west towards the west of the Alps and which points to a Tardiglacial recolonisation of the Alps through the Rhodanian pathway (Briquet 1900; Briquet 1906; Delarze 1987). Several continental species (e.g. Euphorbia seguieriana, Festuca valesiaca, Veronica prostrata, Scorzonera austriaca, Stipa capillata, S. eriocaulis, Thesium linophyllon) show an analogous pattern from the north-east towards the east and most likely followed a similar pathway after having circumvented the Alps (Burga and Perret 1998). It appears that most of the species migrated along the Rhone, but it is also plausible that some taxa (e.g. Alyssoides utriculata, Saxifraga cotyledon) used a mountainous pathway through the low-altitude passes of the Chablais (e.g. Pasde-Morgin, $1370 \mathrm{~m}$; Col de la Forclaz, $1526 \mathrm{~m}$ ). Indeed, recolonisation may have progressed along the slopes adjacent to major valleys, since ice-free terrain became available there for colonization earlier during the Tardiglacial than on the bottom of valleys. However, this hypothesis still needs confirmation.

\section{The transalpine eastern pathway}

Various authors mentioned a transalpine eastern pathway (Briquet 1906; Christ 1920; Brockmann-Jerosch and Brockmann-Jerosch 1926; Merxmüller 1952), but it remains the least documented recolonisation route. Its existence has been suggested by the observation that some species with mainly eastern alpine distribution, which probably survived the last glaciation in eastern alpine refugia, are also found in the Western Alps (e.g. Androsace chamaejasme, Oxytropis jacquinii, Saxifraga aphylla). Two main trajectories can be postulated: either through the external (lower) part of the Bernese Alps (i.e. Berner Oberland) or across high-elevation passes between the eastern and western Alps in the Upper Valais.

Both geographic and floristic evidence indicates that the external part of the Berner Oberland was not a major recolonisation pathway (Welten 1982). The valleys leading to the Bernese Alps mainly have a north-south orientation, so that they could not serve as migration routes from east to west. Furthermore, the Berner Oberland remained glaciated for a longer period than most other areas of the Alps, and was therefore not favourable for extensive migration of plant species (Lüdi 1951). At the same time, the area is relatively species-poor (Christ 1920; Wohlgemuth 2002). Some authors (e.g. Briquet and Cavillier 1918; Christ 1920) proposed that the Berner Oberland was mainly recolonised from the Rhone valley across the Col du Pillon $(1546 \mathrm{~m})$ and the Gemmipass (2314 m).

Passes of the Upper Valais, such as the Furka (2431 m) and the Oberalp (2044 m), which connect the Rhine valley to the Rhone valley and Berner Oberland, did probably not play a major role in the recolonisation of the Western Alps either. Indeed, the Upper Valais represents the distribution limit of many taxa with either eastern or western alpine distributions (Chodat and Pampanini 1902; Merxmüller 1952), which implies that these species were unable to cross the high-elevation passes of this region.

Together, this evidence strongly suggests that few (if any) species recolonised the Western Alps through the transalpine eastern pathway. It therefore seems more plausible that eastern alpine species which presently occur in the Western Alps circumvented the central part of Alps through the northern lowland and recolonised the Western Alps through the Rhodanian pathway. 


\section{The transalpine southern pathway}

The southern Alps were only slightly glaciated during the last glacial maximum, enabling the survival of several alpine species (Wilczek and Vaccari 1910; Guyot 1925). Accordingly, the existence of a migration pathway from south to north through the Pennine Alps may have been crucial for the recolonisation and present biodiversity of the Western Swiss Alps. Several authors have postulated a transalpine southern pathway connecting the Italian Alps (Aosta valley and Piemont) to the Valais trough high-altitude passes (Jaccard 1900; Christ 1920; Guyot 1935; Rytz 1951; Delarze 1987). However, this hypothesis has been debated for a long time because floristic data provided ambiguous evidence.

On one hand, several plant species are restricted to either the Rhone or the Aosta valley, even though the other valley would certainly offer equally suitable habitats. For example, Adonis vernalis, Aethionema saxatile and Gagea saxatilis are confined to the Valais, while Astragalus alopecurus, and Inula montana are restricted to the Aosta valley (Guyot 1935). Furthermore, the Atlantic sector of the Aosta valley is particularly rich in Mediterranean and Insubrian species, which do not extend into the Valais (Guyot 1930). Together, these floristic patterns indicate that migration from the Southern Alps to Valais was restricted.

On the other hand, several rare species of the Pennine Alps reach the northern limit of their distribution in the Valais (Chodat and Pampanini 1902) and for these a transalpine migration seems likely. Furthermore, several species occur both in the Aosta valley and in the Rhone valley, while they are absent from other parts of the Western Alps (e.g. Artemisia vallesiaca, Campanula spicata, Ephedra helvetica, Saxifraga bulbifera), supporting a migration across the line of high-elevation summits (Guyot 1935). This line could have been permeable through several high-altitude passes (Fenêtre de Ferret, 2490 m; Grand St. Bernard, 2475 m; Fenêtre Durand, 2812 m; Col du Collon, $3130 \mathrm{~m}$; Theodulpass, $3333 \mathrm{~m}$; Antronapass, $2844 \mathrm{~m}$; Simplonpass, $2005 \mathrm{~m}$, Fig. 1). Migration over theses passes is particularly conceivable for species which can tolerate high-altitude conditions (several continental and sub-mediterranean species). Furthermore, it is plausible that the predominant southern exposure of the Italian slopes allowed a rapid deglaciation and a great altitudinal expansion of several species (Rytz 1951).

There is ample floristic evidence supporting the migration of species through these high-altitude passes. Several species-rich areas of the Western Alps are situated in the vicinity of passes that may have acted as major recolonisation routes (Fenêtre Durand, Theodulpass and Simplon). Jaccard (1900) observed that the flora of the upper valley of Bagnes resembles that of the Aosta valley more closely than that of the Rhone Valley. Guyot (1921) found that several xerophilous species, which reach an exceptionally high altitude to the south of the Fenêtre Durand, can be continuously observed on both sides of the summit line. The Zermatt region shows a similar pattern (Richard 1985), as it harbours many species from the southern Alps, such as Crepis rhaetica, Phyteuma humile, Potentilla multifida, Pulsatilla halleri, Scutellaria alpina, Silene suecica, Campanula excisa, Koeleria hirsuta, Saxifraga cotyledon and Valeriana celtica (Rytz 1951). This suggests that the Zermatt region has been connected to the Western Piemont through the Theodulpass and/or to the Eastern Piemont through the Antronapass.

The role of the Simplon as a recolonisation pathway is less clear. On the one hand, the Simplon is the lowest major pass crossing the Pennine Alps (2005 m), which should 
have made it a privileged recolonisation pathway for several xerophilous species that survived the glacial periods in the refugia of the Eastern Piemont (Beauverd 1911; Parisod et al. 2006). It has even been suggested that some thermophilous species recolonised the north of the western Swiss Alps through the Simplon and then through the Gemmipass or the Lötschenpass (Briquet and Cavillier 1918). The high floristic diversity of the Simplon region is consistent with these hypotheses.

Besides natural migrations, human transport has also introduced some species from the Aosta valley to the Valais (e.g. Pisum sativum ssp. biflorum, Ruta graveolens, Tulipa grengiolensis). Transalpine exchanges of Vitis vinifera, apparently across the Col du Grand St. Bernard, have been demonstrated by molecular analyses (Vouillamoz et al. 2003). Likewise, archaeological studies of human migrations within the Alps indicate that cultural and technical exchanges between the northern and the southern Alps mainly occurred over the passes, rather than along major valleys (Curdy and Praz 2002; Gallay 2006).

\section{Results of molecular studies}

Only few molecular studies so far have been sufficiently comprehensive to supply reliable information about postglacial recolonisation routes. The reconstruction of recolonisation pathways relies on the identification of clines of genetic diversity at the infraspecific level. Given the complex topography of the Alps, migration routes and distribution patterns of genotypes are likely to be complex as well. The identification of clines therefore requires the sampling of many populations within a region as well as the use of molecular markers providing enough polymorphism to achieve a sufficient phylogenetic resolution.

The most extensive molecular study carried out so far in the Western Alps concerned the widespread Biscutella laevigata (Brassicaceae). In this research, 268 individuals from 67 populations were collected in putative refugia as well as in previously glaciated areas across the altitudinal range of the species (from $440 \mathrm{~m}$ to $2450 \mathrm{~m}$ ). Phylogenetic relationships were analysed with chloroplast sequences presenting a high mutation rate (Parisod and Besnard 2007). Since B. laevigata has no known human usage, it is unlikely that it was deliberately transported by humans, so that present patterns of distribution probably result from natural migration. The results showed that $B$. laevigata survived the ice ages in refugia of the external Alps as well as in central nunatacks. Some infraspecific lineages stayed confined to these refugia, while others recolonised the Alps in the course of a rapid postglacial radiation. At least three independent lineages recolonised the western Alps of Switzerland, and their present distribution indicates the recolonisation pathways used by the species (Fig. 2).

One lineage of B. laevigata apparently used the Rhodanian pathway from the west towards the Valais (Parisod and Besnard 2007). Indeed, populations around the Rhone valley were genetically related, and genetic diversity declined from the external Alps towards the central Valais, as would be expected if plants have migrated along this route. Furthermore, while populations from the Bernese and the northern Pennine Alps showed a comparable genetic diversity, lowland populations along the Rhone were homogeneous, with a single genotype. This pattern indicates that the species first migrated along the slopes next to the Rhone, and then colonised the valley bottom from a subset of the subalpine populations. This evidence corroborates the hypothesis 


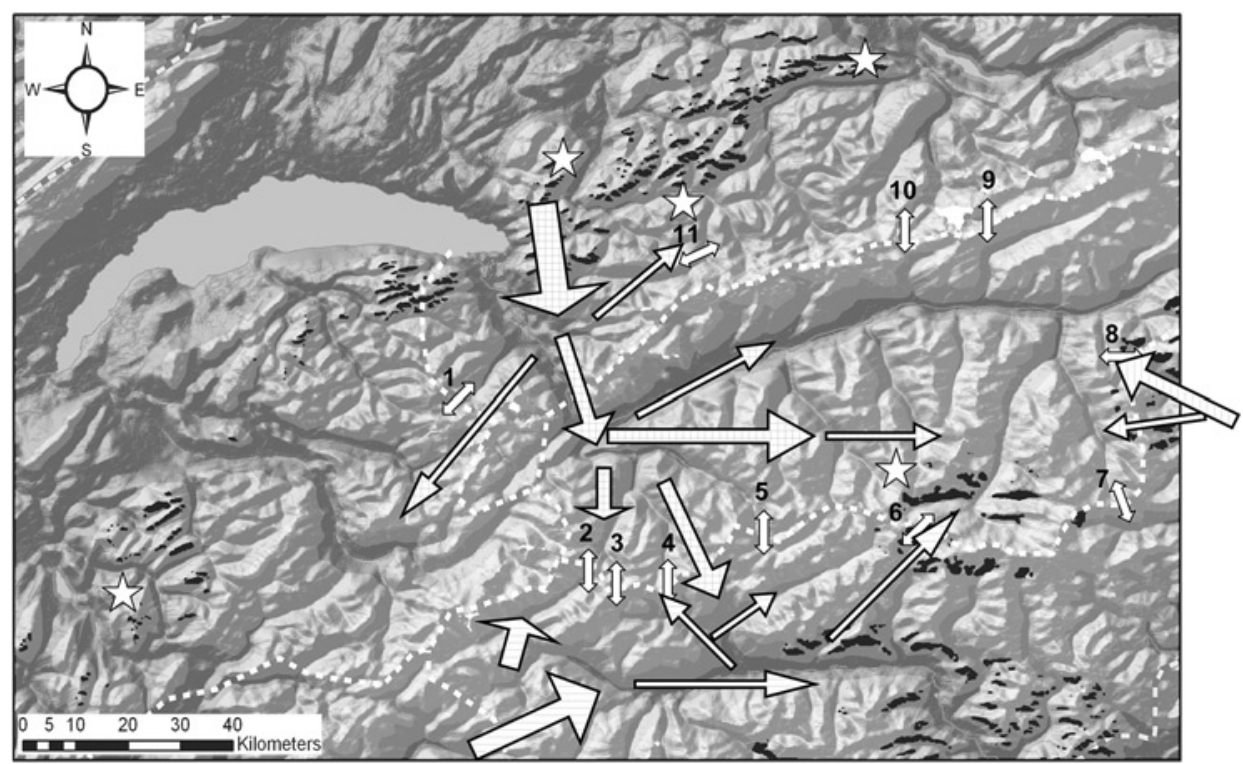

Fig. 2. Post-glacial recolonisation of Biscutella laevigata in the western Alps of Switzerland, summarised from the pattern of genetic diversity available in Parisod and Besnard (2007). The basemap is presented according to Figure 1b. Stars indicate the refugial areas with restricted infraspecific lineages. The arrows, whose widths reflect the observed amount of genetic diversity, describe the dynamics of migration. The cross-striped arrows present the recolonisation of the northern lineage of B. laevigata, while the horizontal-striped arrows indicate the pathways used by the southern lineage. The vertical-striped arrow represents the lineage from the "Eastern Piemont" that reached the Simplon area.

mentioned above (section "Rhodanian pathway") that slopes became available for colonization earlier than the bottom of valleys.

While this first lineage was largely restricted to the north of the Pennine Alps, a second one was distributed over the south of the Pennine Alps, indicating that the line of high summits between these two regions acted as a major barrier to recolonisation (Parisod and Besnard 2007). However, exceptions to this clear-cut pattern provide support for immigration through the transalpine southern pathway. On one hand, populations of the northern lineage were also found near the Ollomont valley in the south of the Alps, showing that the species crossed the Pennine summit line towards the south, most probably through the Fenêtre Durand $(2812 \mathrm{~m})$. On the other hand, the southern lineage reached the north of the Pennine Alps around Zermatt, through the Val Tournanche and the Theodulpass $(3333 \mathrm{~m})$. Given that these passes are now too high to provide favourable habitats for the species, B. laevigata probably crossed the Pennine Alps during the climatic optimum, about 6000 years before present.

A third lineage of $B$. laevigata, coming from the Eastern Piemont, probably migrated over the Simplon (Parisod and Besnard 2007; Parisod et al. 2006) and then reached the region of Zermatt through the Antronapass $(2844 \mathrm{~m})$ or the Zwischenbergenpass $(3248 \mathrm{~m})$. This eastern lineage did not expand further into the Valais, probably because it had to migrate along a tortuous pathway and reached this area 
relatively late, when the region was already occupied by other lineages. A few other molecular studies also pointed to the role of the Simplon as a recolonisation pathway, which was suggested for Onosma helvetica (Vouillamoz 2001) and an Oak lineage (Mátyás and Sperisen 2001). The latter study also indicated that oaks further reached the northern peripheral Alps through the Gemmipass.

\section{Implications for biodiversity within the Alps}

Across the European continent, postglacial migration has been characterised by recurrent foundation of allopatric populations through long-distance dispersal and by a decrease in genetic diversity along recolonisation pathways (Hewitt and Ibrahim 2001). In some cases, genetic diversity has been replenished by a secondary admixture of independent lineages recolonising the landscape from separate refugia (Petit et al. 2003). This pattern also applies to Biscutella laevigata within the western Swiss Alps. Indeed, its genetic diversity is high in the refugia of the external Alps and decreases towards the central Alps. Within the central Alps, however, genetic diversity is particularly high in the region of Zermatt, where three independent recolonising lineages merged (Parisod and Besnard 2007). Therefore, the species history, including in situ survival as well as admixture of distantly related lineages, accounts for the high level of regional diversity encountered in the central Alps. Since the widespread $B$. laevigata followed recolonisation pathways that were generally congruent with those postulated on floristic evidence, many species may have had analogous histories. Similar studies for other species will be needed to confirm that the species history participated in shaping the patterns of biodiversity presently observed within the western Swiss Alps.

\section{Résumé}

Durant les glaciations du Quaternaire, les plantes alpines n'ont pu persister que dans quelques zones épargnées par les glaces, à l'intérieur des Alpes ou à leur périphérie. De là, les espèces ont recolonisé les Alpes lors du retrait glaciaire. La localisation des refuges glaciaires et des voies de recolonisation a traditionnellement été postulée à partir de l'aire de répartition d'espèces caractéristiques. La phylogéographie moléculaire, c'est-à-dire l'étude de la distribution des génotypes dans l'espace et dans le temps, a récemment permis de confirmer certains refuges intra-alpins, mais les voies de migration sont restées vagues. La littérature floristique est ici passée en revue pour présenter une carte synthétique des voies de recolonisation potentielles pour les Alpes occidentales de Suisse. Trois voies principales sont suggérées : la voie Rhodanienne (depuis les refuges du sud-ouest, le long de la vallée du Rhône), la voie transalpine méridionale (depuis les refuges du sud, à travers les cols de haute altitude le long des hauts sommets des Alpes), et la voie transalpine orientale (depuis les refuges de l'est, le long de la vallée du Rhin et à travers les Alpes du nord). La distribution de nombreuses espèces le long du Rhône soutient l'hypothèse de la voie Rhodanienne. De même, la présence de plusieurs espèces méridionales aux alentours de certains cols transalpins illustre celle de la voie transalpine méridionale. A l'inverse, peu d'espèces présentent une distribution en accord avec la voie transalpine orientale. De récentes études moléculaires soutiennent ces apports de la floristique. En particulier, la 
répartition de différentes lignées génétiques de Biscutella laevigata, une espèce alpine fréquente, indique une recolonisation par la voie Rhodanienne et par la voie transalpine méridionale. De plus, cette espèce présente une diversité génétique remarquable au centre des Alpes, où différentes lignées se rencontrent. Une meilleure connaissance des voies de migration empruntées lors du réchauffement post-glaciaire est essentielle afin de comprendre la réaction des espèces aux changements climatiques et la biodiversité au sein des Alpes.

I would like to thank L. Bavaud, N. Galland, A. Guisan, R. Holderegger, P. Taberlet and P. Vittoz for their help while preparing this manuscript, as well as anonymous reviewers and S. Güsewell for their constructive comments.

\section{References}

Aeschimann D., Lauber K., Moser D.M. et Theurillat J.-P. 2004. Flora alpina. Haupt, Bern/ Stuttgart/Wien.

Beauverd G. 1911. Excursion phanérogamique de la Murithienne de Viège à Visperterminen et au Simplon. Bull. Murithienne 29: 153 - 156.

Bettin O., Cornejo C., Edwards P.J. and Holderegger R. 2007. Phylogeography of the high alpine plant Senecio halleri (Asteraceae) in the European Alps: in situ glacial survival with postglacial stepwise dispersal into peripheral areas. Mol. Ecol. 16: 2517 - 2524.

Briquet J. 1890. Recherches sur la flore du district savoisien et du district jurassique francosuisse. Engler's bot. Jahrbuch 13: $47-105$.

Briquet J. 1900. Les colonies végétales xérothermiques des Alpes lémaniennes. Une contribution à l'histoire de la période xérothermique. Bull. Murithienne 28: 125 - 212.

Briquet J. 1906. Le développement des flores dans les Alpes occidentales, avec aperçu sur les Alpes en général. In: vonWettstein R., Wiesner J. und Zahlbruckner A. (eds.). Wissenschaftliche Ergebnisse des Internationalen Botanischen Kongresses Wien 1905. Gustav Fischer, Jena, 130 - 173.

Briquet J. et Cavillier F. 1918. Notes sur quelques phanérogames de l'Oberland bernois. Ann. Cons. Jard. Bot. Genève 20: 221 - 261.

Brockmann-Jerosch H. und Brockmann-Jerosch M. 1926. Die Geschichte der Schweizerischen Alpenflora. In: Schröter C. (ed.). Das Pflanzenleben der Alpen. Raustein, Zürich, 1110 1215.

Burga C.A. und Perret R. 1998. Vegetation und Klima der Schweiz seit dem jüngeren Eiszeitalter. Ott, Thun.

Chodat R. et Pampanini R. 1902. Sur la distribution des plantes dans les alpes austro-orientales et plus particulièrement d'un choix de plantes des alpes cadoriques et venitiennes. Le Globe 41: 1 - 70 .

Christ H. 1920. La flore de la Suisse. Georg and Cie, Bâle-Genève-Lyon.

Comes H.P. and Kadereit J.W. 1998. The effects of Quaternary climatic changes on plant distribution and evolution. Trends Plant Sci. 3: 432 - 438.

Curdy P. et Praz J.C. 2002. Premiers hommes dans les Alpes de 50000 à 5000 avant Jésus-Christ. Catalogue de l'exposition, Sion 2002. Payot, Lausanne.

Delarze R. 1987. L'origine des pelouses steppiques valaisannes à la lumière de leurs liens de parenté avec les régions limitrophes. Bull. Murithienne 105: 41 - 70.

Gallay A. 2006. Des Alpes au Léman. Images de la préhistoire. Infolio éditions, Gollion.

Gugerli F. and Holderegger R. 2001. Nunatak survival, tabula rasa and the influence of the Pleistocene ice-ages on plant evolution in mountain areas. Trends Plant Sci. 6: 397 - 398.

Guyot H. 1921. Contribution phytogéographique sur le versant méridional des Alpes Pennines. Bull. Soc. Bot. Genève 13: 185 - 216. 
Guyot H. 1925. Contribution sur la phytogéographie des Alpes graies orientales. Flore Valdôtaine 18: 3 - 19 .

Guyot H. 1930. La flore des secteurs valaisans et valdôtains à climat subatlantique. Bull. Soc. Bot. Genève 22: 1 - 13 .

Guyot H. 1935. Phytogéographie comparée du Valais et de la vallée d'Aoste. Bull. Murithienne 52: $16-35$.

Hewitt G.M. and Ibrahim K.M. 2001. Inferring glacial refugia and historical migrations with molecular phylogenies. In: Silvertown J. and Antonovics J. (eds.). Integrating ecology and evolution in a spatial context. Blackwell Science, Oxford, 271 - 294.

Jaccard P. 1900. Contribution au problème de l'immigration post-glaciaire de la flore alpine. Bull. Soc. Vaud. Sc. Nat. 36: $87-130$.

Kelly M.A., Buoncristiani J.F. and Schlüchter C. 2004. A reconstruction of the last glacial maximum (LGM) ice-surface geometry in the western Swiss Alps and contiguous Alpine regions in Italy and France. Eclogae Geol. Helv. 97: 57 - 75.

Körner C. 1999. Alpine Plant Life. Functional Plant Ecology of High Mountain Ecosystems. Springer, Heidelberg.

Laydu-Mange N. 1999. Démographie et variabilité génétique de Koeleria vallesiana Honck. Gaudin (Poaceae) dans les pelouses steppiques valaisannes. $\mathrm{PhD}$ thesis, University of Lausanne.

Lüdi W. 1951. Oberland bernois. In: Chouard P., Gauss H. et Vischer W. (eds.). Coupe Botanique des Alpes du Tyrol à la France. Bull. Soc. Bot. Fr.: 65 - 69.

Mátyás G. and Sperisen C. 2001. Chloroplast DNA polymorphism provide evidence for postglacial re-colonisation of oaks Quercus spp. across the Swiss Alps. Theor. Appl. Gen. 102: $12-20$.

Merxmüller H. 1952. Untersuchungen zur Sippengliederung und Arealbildung in den Alpen, I. Jb. Ver. Schutze d. Alpenpflanzen u. Tiere 17: $96-133$.

Ozenda P. 1995. L'endémisme au niveau de l'ensemble du Système alpin. Acta Bot. Gallica 142: $753-762$.

Ozenda P. 2002. Perspectives pour une géobiologie des montagnes. Presses Polytechniques et Universitaires Romandes, Lausanne.

Parisod C. and Besnard G. 2007. Glacial in situ survival in the Western Alps and polytopic autopolyploidy in Biscutella laevigata L. (Brassicaceae). Mol. Ecol. 16: 2755 - 2767.

Parisod C., Besnard G. et Hainard P. 2006. Le Simplon : voie de transit pour les plantes et carrefour de la biodiversité alpine. Actes du Colloque Simplon $1806-2006$. Un axe européen. Société d'histoire de la Suisse romande et l'Association Commémorations du Simplon, Lausanne.

Pawlowski B. 1970. Remarques sur l'endémisme dans la flore des Alpes et des Carpates. Vegetatio 21: $181-243$.

Petit R.J., Aguinagalde I., De Beaulieu J.L., et al. 2003. Glacial refugia: hotspots but not melting pots of genetic diversity. Science 300: $1563-1565$.

Richard J.L. 1985. Les pelouses xérophiles de la région de Zermatt. Bot. Helv. 95: 193 - 211.

Rytz W. 1951. Environs de Zermatt et de Saas. Le rôle biogéographique des cols. In: Chouard P., Gauss H. et Vischer W. (eds.). Coupe Botanique des Alpes du Tyrol à la France. Bull. Soc. Bot. Fr.: $77-78$.

Schönswetter P., Stehlik I., Holderegger R. and Tribsch A. 2005. Molecular evidence for glacial refugia of mountain plants in the European Alps. Mol. Ecol. 14: 3547 - 3555.

Stehlik I. 2000. Nunataks and peripheral refugia for alpine plants during quaternary glaciation in the middle part of the Alps. Bot. Helv. 110: 25 - 30 .

Theurillat J.-P., Aeschimann D., Küpfer P. et Spichiger R. 1993. Habitats et régions naturelles des Alpes. Colloq. Phytosoc. 22: 15 - 30.

Tribsch A. and Schönswetter P. 2003. Patterns of endemism and comparative phylogeography confirm palaeo-environmental evidence for Pleistocene refugia in the Eastern Alps. Taxon 52: 477 - 497. 
Vellend M. and Geber M.A. 2005. Connections between species diversity and genetic diversity. Ecol. Letters 8: $767-781$.

Vouillamoz J. 2001. Approches cytotaxonomique et moléculaire de la phylogéographie des taxons du genre Onosma (Boraginaceae) en Suisse et dans les pays limitrophes. PhD Thesis, Université de Lausanne.

Vouillamoz J., Maigre D. and Meredith C.P. 2003. Microsatellite analysis of ancient alpine grape cultivars: pedigree reconstruction of Vitis vinifera L. 'Cornalin du Valais'. Theor. Appl. Gen. 107: 448 - 454.

Welten M. 1982. Vegetationsgeschichtliche Untersuchungen in den westlichen Schweitzer Alpen: Bern-Wallis. Mém. Soc. Helv. Sc. Nat. 95: 12 - 27.

Wilczek E. et Vaccari L. 1910. Note sur la végétation du versant méridional des Alpes Graies orientales. Bull. Soc. Vaud. Sc. Nat. 46: $1-8$.

Wohlgemuth T. 2002. Environmental determinants of vascular plant species richness in the Swiss alpine zone. In: Körner C. and Spehn E.M. (eds.). Mountain biodiversity, a global assessment. Parthenon, Boca Raton, Florida: 103 - 116. 